\title{
TRANSFORMASI MEDIA MASSA MENUJU ERA MASYARAKAT INFORMASI DI INDONESIA
}

\author{
Wira Respati \\ Marketing Communication Department, Faculty of Economic and Communication, BINUS University \\ Jln. K.H. Syahdan No.9, Palmerah, Jakarta Barat 11480 \\ warespati@gmail.com
}

\begin{abstract}
Indonesia is now on the transition toward the Age of Information Society. In this period, the pattern of gathering as well as distributing information change. This situation is in accordance with the change of human lifestyle as the concequences of Information Communication Technology (ICT) adoption. Their tools in communicating offer more opportunies and interactive characteristics. Moreover, the use of social media applications, which one of them is blog based on web 2.0, opens possibilities for the audience to give more active roles in gathering and distributing news, just like what professional journalists do. The question now is about how the practioners of mainstream news face this phenomenon, what they should do to maintain their existence in media industry. They should not ignore the growth of virtual community as well as citizen journalism. They cannot also pretend that there is no change on their audience behavior in consuming media. On the contrary, they do need to give space to their audiences who are in transtition toward the age of information society, to participate creatively in gathering and producing information.
\end{abstract}

Keywords: transformation, news media, information society

\begin{abstract}
ABSTRAK
Masyarakat Indonesia saat ini tengah berada dalam fase transisi menuju masyarakat era informasi. Dalam proses ini terdapat pergeseran pola masyarakat dalam mengakses dan mendistribusikan informasi. Hal ini merupakan perubahan gaya hidup yang sebagai konsekuensi penggunaan perangkat komunikasi berbasis teknologi informasi (ICT). Inovasi fitur perangkat komunikasi saat ini menawarkan medium komunikasi yang kian interaktif. Satu yang paling vital di antaranya Blog, aplikasi sosial media berbasis web 2.0, menawarkan kapasitas produksi dan distribusi informasi yang mendorong masyarakat untuk berperan aktif tidak hanya sebatas mengonsumsi tetapi juga memproduksi berita seperti halnya jurnalis profesional. Praktisi industri media pemberitaan mainstream menghadapi fenomena ini idak boleh mengabaikan pergeseran perilaku khalayak dalam mengonsumsi dan mendistribusikan informasi. Mereka juga tidak dapat menampik kebangkitan era komunitas virtual dan pewarta warga. Pada era masyarakat informasi, praktisi media mainstream harus berdamai dengan bertransformasi menjadi media pemberitaan yang memberikan ruang kreativitas bagi khalayaknya untuk turut berpartisipasi aktif memproduksi informasi.
\end{abstract}

Kata kunci: transformasi, media pemberitaan, masyarakat informasi 


\section{PENDAHULUAN}

Saat ini, memahami eksistensi media pemberitaan tidak cukup hanya dengan mengkaji cara kerja praktisi serta khalayak dalam upaya mememenuhi kebutuhan informasi. Hal tersebut memerlukan juga penelusuran tentang perubahan konsep media pemberitaan yang dipengaruhi perkembangan teknologi pendukungnya. Konsep media senantiasa mengikuti dinamika peradaban manusia yang saat ini telah memasuki era masyarakat informasi (Aoyama \& Castells, 2002). Jika dibandingkan dengan era sebelumnya (era masyarakat pertanian dan era masyarakat industri), media penyiaran abad ini memiliki karakteristik yang semakin kompleks. Sebagai ilustrasi, dapat dilihat bagaimana karakteristik media penyiaran televisi di Indonesia pada masa orde baru (1966-1998). Kala itu media pemberitaan terpasung kebijakan politik orde baru, utamanya media televisi yang didominasi stasiun televisi TVRI atau Televisi Republik Indonesia (Hermanto, 2007). Penyiaran dan produksi materi berita berlangsung di bawah kontrol pemerintah. Model komunikasi yang berlaku adalah model komunikasi Wilbur Schram yang dikenal dengan model komunikasi Source-MessageChannel-Receiver (SMCR) atau model komunikasi yang berlangsung linier dari sumber-pesan-saluran hingga penerima informasi. Rezim penguasa yakni pemerintahan orde baru menguasai dan mengontrol pesan atau informasi dan khalayak menerimanya tanpa memiliki peluang luas untuk memberikan feedback atau umpan balik. Media komunikasi massa saat itu bersifat dari satu pihak ke massa dengan umpan balik yang terbatas (Straubhaar \& LaRose, 2006).

Sebaliknya, model komunikasi yang diterapkan pascaorde baru telah menyertakan unsur umpan balik. Industri media penyiaran Indonesia saat ini telah membuka keran bagi masyarakat untuk memberikan umpan balik terhadap isi berita yang disiarkan, sebut saja program acara Suara Anda (Metro TV) yang disiarkan pada 19.05 - 20.00 WIB. Program acara ini memungkinkan khalayaknya dapat berinteraksi dengan memilih dan mengomentari berita pilihannya. Tak ketinggalan program berita Liputan 6 (SCTV) memberikan ruang bagi khalayak untuk menyiarkan berita yang mereka himpun sendiri melalui program tayangan terrestrialnya Liputan 6 Pagi Akhir Pekan termasuk kanal Citizen 6 untuk Citizen Journalism atau pewarta warga pada portal berita liputan6.com. Fenomena ini menjelaskan adanya unsur interaktivitas yang menjadi ciri khas media pemberitaan era masyarakat informasi, yang di dalamnya, khalayak tak cuma memiliki kesempatan untuk memberikan pesan namun memodifikasi isi pesan yang disajikan (Straubhaar \& LaRose, 2006)

Selain interaktivitas yang ditawarkan, media pemberitaan baru juga memiliki karakteristik yang tidak kalah penting, yaitu digitalisasi. Tidak dapat dipungkiri lagi, media penyiaran dengan platform digital memiliki banyak kelebihan dibandingkan media analog atau konvensional. Selain membuka jalur komunikasi dua arah, media baru era informasi memiliki performa kualitas tayangan serta sebaran yang lebih luas. Karakter terakhir yang diusung adalah Audience Generated, bahwa media baru memungkinkan khalayak mendistribusikan konten yang mereka himpun sendiri (Straubhaar \& LaRose, 2006).

Pada era masyarakat informasi industri media massa mau tidak mau harus bertransformasi dari bentuk analog menjadi digital. Karena ciri khas produk teknologi di era ini menawarkan produktivitas, efisiensi, kecepatan dan lintas batas. Perangkat komunikasi teks, audio dan visual yang sebelumnya terpisah kini berpadu dan konvergen dalam satu perangkat transmisi yang menggabungkan fungsi media penyiaran lama ke dalam satu platform media baru. Semuanya didukung oleh jaringan global Internet, yang bahwa media massa, komputer, dan jaringan telekomunikasi saling berintegrasi atau belakangan lazim disebut sebagai konvergensi media (Straubhaar \& LaRose, 2006).

Perlu diperhatikan pula, munculnya Internet tak dapat dilihat secara parsial sebagai hasil sebuah evolusi teknologi namun juga aspek budaya yang melihat teknologi dari sisi tujuan, nilai, kode 
etik, keyakinan akan kemajuan, kesadaran dan kreativitas (Pacey, 2000). Kehadiran teknologi Internet dapat dimaknai sebagai perangkat yang mengubah tatanan produksi dan distribusi informasi, yang bahwa khalayak juga memiliki peran signifikan bukan hanya penyelenggara atau praktisi industri media.

Perangkat komunikasi yang makin konvergen juga punya andil besar dalam perubahan tatanan distribusi informasi saat ini. Kamera yang terintegrasi dalam perangkat komunikasi nirkabel membuat informasi yang dihimpun menjadi lebih lengkap karena didukung visualisasi dari tempat peristiwa (Brown, 2012). Masyarakat atau khalayak dapat mendistribusikan informasi yang memiliki nilai berita, lebih cepat ketimbang seorang jurnalis sekalipun. Jika sudah begini, praktis pelaku industri media pemberitaan harus berpikir ulang guna menjaga eksistensi mereka sebagai penyaji informasi faktual mengikuti perkembangan teknologi komunikasi dan gaya hidup masyarakat yang mengiringnya. Mereka harus mengakomodasi kebangkitan Citizen Journalism atau pewarta warga, yang kemudian membuka keran partisipasi aktif masyarakat untuk mengumpulkan, memilih, dan melaporkan informasi yang memiliki nilai berita (Flew, 2008).

Kebangkitan Citizen Journalism atau pewarta warga berhubungan erat dengan meluasnya jaringan sosial media yang mengiringi perkembangan Information Communication Technology atau teknologi komunikasi informasi (ICT). Kehadiran media sosial memperlihatkan teknologi informasi dan komunikasi telah merambah semua aspek kehidupan manusia dalam konteks membangun hubungan sosial (Flew, 2008). Jaringan distribusi informasi melalui infrastruktur Internet praktis lebih luas bahkan bersifat global ketimbang jaringan media pemberitaan konvensional. Pola distribusi informasi pun beragam karena social software atau perangkat sosial yang berkembang lebih dari satu macam, seperti Blog, Facebook, Twitter, Youtube dengan kelebihan dan kekurangan masing-masing. Praktis yang menjadi pertanyaan kemudian adalah tentang hal yang harus dilakukan praktisi media penyiaran profesional yang sudah ada dalam menyambut fenomena tersebut, dan mereka melihatnya sebagai suatu ancaman atau justru sebagai sebuah peluang.

\section{METODE}

Guna memahami transformasi industri media massa di Indonesia menyongsong era masyarakat informasi, penelitian menggunakan metode kualitatif untuk menggali lebih dalam hal-hal yang melatarbelakangi transformasi itu sendiri. Riset kualitatif bertujuan untuk menjelaskan fenomena sedalam-dalamnya. Di sini yang lebih ditekankan adalah persoalan kedalaman (kualitas) data bukan banyaknya (kuantitas) data (Kriyantono, 2012). Format desain penelitian ini adalah deskriptif. Penelitian bertujuan untuk menggambarkan, meringkaskan berbagai kondisi, berbagai situasi atau berbagai fenomena realitas sosial yang ada di masyarakat yang menjadi objek penelitian. Selain itu, penelitian didukung dengan studi literatur pada penelitian sebelumnya, terkait dengan karakteristik era masyarakat informasi yang membuat industri media massa mainstream negeri ini harus melakukan transformasi dengan mengadopsi teknologi informasi dan komunikasi (ICT).

Pengumpulan data dilakukan melalui studi kepustakaan dilengkapi dengan wawancara praktisi televisi terkait upaya dan langkah yang telah dilakukan dalam proses transformasi itu sendiri. Data diperoleh dari para key informan yang terlibat dalam proses transformasi yang dilakukan manajemen redaksi pemberitaan televisi Liputan 6 SCTV. Saat ini mereka telah mengembangkan portal berita liputan6.com sebagai outlet berita yang mengadopsi teknologi komunikasi informasi (ICT). Liputan 6 SCTV juga mengikuti tren Citizen Journalism atau pewarta warga yang menandai era masyarakat informasi sekaligus memberikan ruang kepada khalayak, untuk memproduksi sekaligus mendistribusikan informasi berita secara mandiri. 


\section{HASIL DAN PEMBAHASAN}

Masyarakat informasi adalah sebuah konsep yang digunakan untuk mendeskripsikan sebuah masyarakat yang dapat memaksimalkan informasi dan teknologi komunikasi baru (ICT). Mereka memanfaatkan teknologi baru tersebut dalam berbagai sendi kehidupan seperti ekonomi, politik, sosial dan budaya. Masyarakat berinteraksi dalam komunitas virtual, termasuk di dalamnya menghimpun hingga berbagi informasi. Tatanan dalam memperoleh informasi tidak hanya mengandalkan media massa yang bersifat kovensional dan mainstream. Di kancah global era masyarakat informasi ditandai dengan kemunculan perangkat komputer pada 1975 yang mendukung kegiatan membuat, memproses, dan menyimpan informasi hingga kemudian pada 1991 lahir world wide web atau jaringan informasi global berbasis web yang didukung infrastruktur jaringan Internet (Straubhaar \& LaRose, 2006).

\section{Indonesia, Transisi Menuju Era Masyarakat Informasi}

Di Indonesia konsep Information Society atau masyarakat informasi sebenarnya sudah digaungkan lebih dari satu dekade silam. Pertanyaan yang mengemuka adalah apakah masyarakat negeri ini sudah dapat dikategorikan sebagai masyarakat informasi. Sejauh ini belum ada kajian yang benar-benar secara gamblang mentasbihkan kesiapan Indonesia menyongsong era masyarakat informasi. Menurut Gambar 1 berdasarkan data Internet World Stat (2012), Indonesia menempati peringkat empat Asia sebagai negara dengan pengguna Internet terbanyak. Data ini lazimnya juga digunakan pemerintah Indonesia untuk melihat profil pengguna Internet yang saat ini sekitar 55 juta masyarakat Indonesia sudah terakses dengan media berbasis teknologi informasi dan komunikasi.

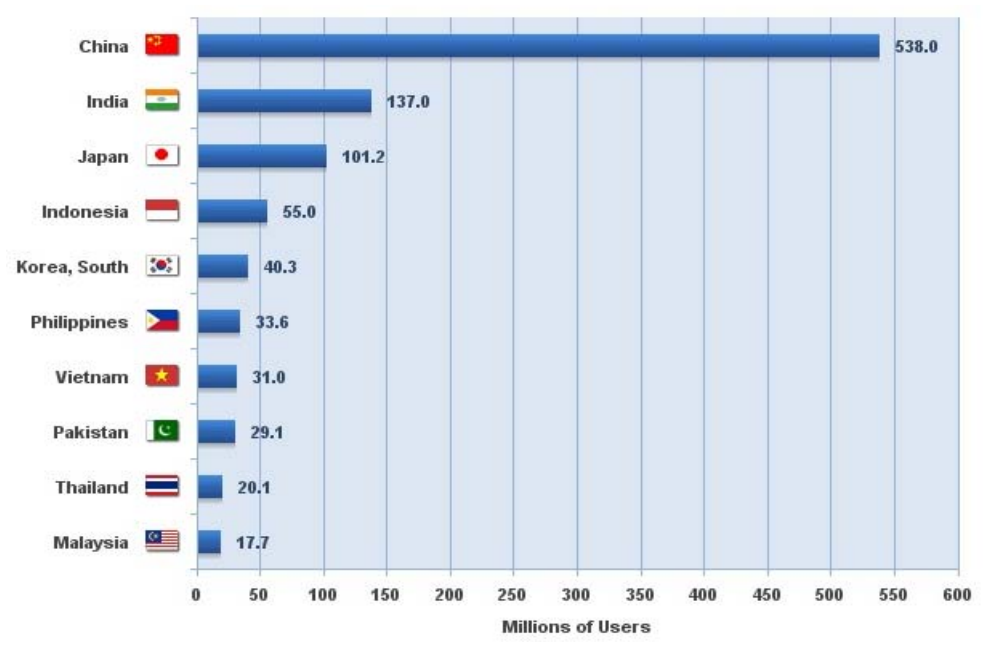

Gambar 1 Profil Negara di Asia dengan Pengguna Internet Terbanyak (Sumber: Internet World Stats, 2012)

Namun demikian, perilaku penggunaan media baru berbasis teknologi informasi komunikasi (ICT) tidak serta merta berlaku dalam sekejap. Meskipun banyak penduduk Indonesia yang menggunakan Internet, tidak semua warga melek teknologi. Faktor geografis dan perekonomian adalah penyebabnya. Wilayah Indonesia yang sangat luas dari Sabang sampai Merauke menyebabkan distribusi pendidikan, perekonomian, dan bahkan teknologi belum merata. Teori difusi Everett M. Rogers dalam Straubhaar dan LaRose (2006) mengatakan bahwa perubahan dikomunikasikan melalui saluran tertentu dalam jangka waktu tertentu di antara para anggota suatu sistem sosial. Masyarakat Indonesia sebagai negara berkembang membutuhkan waktu dalam penyebaran atau penetrasi teknologi informasi komunikasi (ICT) hingga ke berbagai penjuru wilayah nusantara. Biaya, 
ketersediaan infrastruktur, sosial dan budaya, serta wilayah geografis kerap jadi alasan. Jika dibandingkan berdasarkan wilayah Indonesia, tingkat kepemilikan komputer dalam rumah tangga di wilayah Jawa paling tinggi, diikuti wilayah Kalimantan. Sedangkan wilayah timur Indonesia memiliki tingkat pemilikan yang paling kecil (Meiningsih, 2011).

Teknologi Informasi Komunikasi (ICT) memegang peranan sebagai teknologi kunci (enabler technology) menuju era masyarakat informasi. Indeks Pembangunan teknologi informasi komunikasi (ICT) internasional (International Development Indeks) yang dikembangkan oleh International Telecomunication Union (ITU) bertujuan untuk mengukur: 1) perkembangan teknologi informasi komunikasi suatu negara relatif terhadap negara- negara lain; 2) kemajuan pengembangan teknologi informasi komunikasi (ICT) antara negara-negara berkembang dan negara maju; 3) kesenjangan digital dalam pengembangan teknologi informasi komunikasi (ICT) di berbagai negara sesuai dengan tingkatannya; dan 4) potensi pengembangan teknologi informasi komunikasi (ICT) beberapa negara sejauh mana suatu negara dapat menggunakan teknologi informasi komunikasi (ICT) untuk meningkatkan pertumbuhan dan pembangunan berdasarkan kemampuan dan keterampilan yang tersedia (Meiningsih, 2011). Kesiapan Indonesia menuju era masyarakat informasi dapat dilihat dari indeks perkembangan teknologi informasi dan komunikasi ITU 9 (Tabel 1) sebagai berikut.

Tabel 1 Peringkat Indeks Perkembangan TIK Indonesia dan Beberapa Negara di Asia

\begin{tabular}{|lcc|} 
Negara & $\begin{array}{c}\text { Rank } \\
\mathbf{2 0 0 7}\end{array}$ & $\begin{array}{c}\text { Rank } \\
\mathbf{2 0 0 8}\end{array}$ \\
\hline South Korea & 2 & 3 \\
Japan & 17 & 8 \\
\hline Singapore & 16 & 14 \\
Brunei Darussalam & 39 & 42 \\
\hline Malaysia & 50 & 56 \\
Thailand & 74 & 76 \\
\hline Philippines & 81 & 90 \\
\hline Vietnam & 106 & 86 \\
\hline Indonesia & 109 & 107 \\
\hline LAO P.D.R & 123 & 118 \\
\hline Myanmar & 104 & 119 \\
Cambodia & 122 & 120
\end{tabular}

(Sumber: International Telecommunication Union, 2010)

Data International Telecommunication Union (ITU) menunjukkan, bahwa pada 2008 perkembangan TIK Indonesia berada pada peringkat 107, jauh di bawah peringkat negara-negara ASEAN seperti Vietnam yang memiliki peringkat 86, Philippines 90, Thailand 76 atau bahkan Singapura pada pada peringkat 14 . Situasi ini tentu memprihatinkan mengingat peran teknologi informasi dan komunikasi dalam berbagai aspek kehidupan manusia akan menentukan daya saing nasional. Dengan begitu pemerintah Indonesia melalui Kemenkominfo masih harus berjibaku mengentaskan kesenjangan teknologi yang terjadi di Indonesia. Pemanfaatan teknologi informasi dan komunikasi seutuhnya adalah hal yang mutlak dalam upaya memenuhi kebutuhan hidup dan berkompetisi dalam era masyarakat informasi global.

Terlepas dari paparan indeks perkembangan teknologi dan informasi (ICT) dan penetrasi Internet yang terbilang lambat, tetap saja perkembangan pengguna Internet di Indonesia menunjukkan pertumbuhan yang pesat. Utamanya dalam kurun waktu empat tahun terakhir terjadi lojakan, lebih dari 15 persen dari 100 masyarakat Indonesia saat ini sudah terakses dengan Internet. 


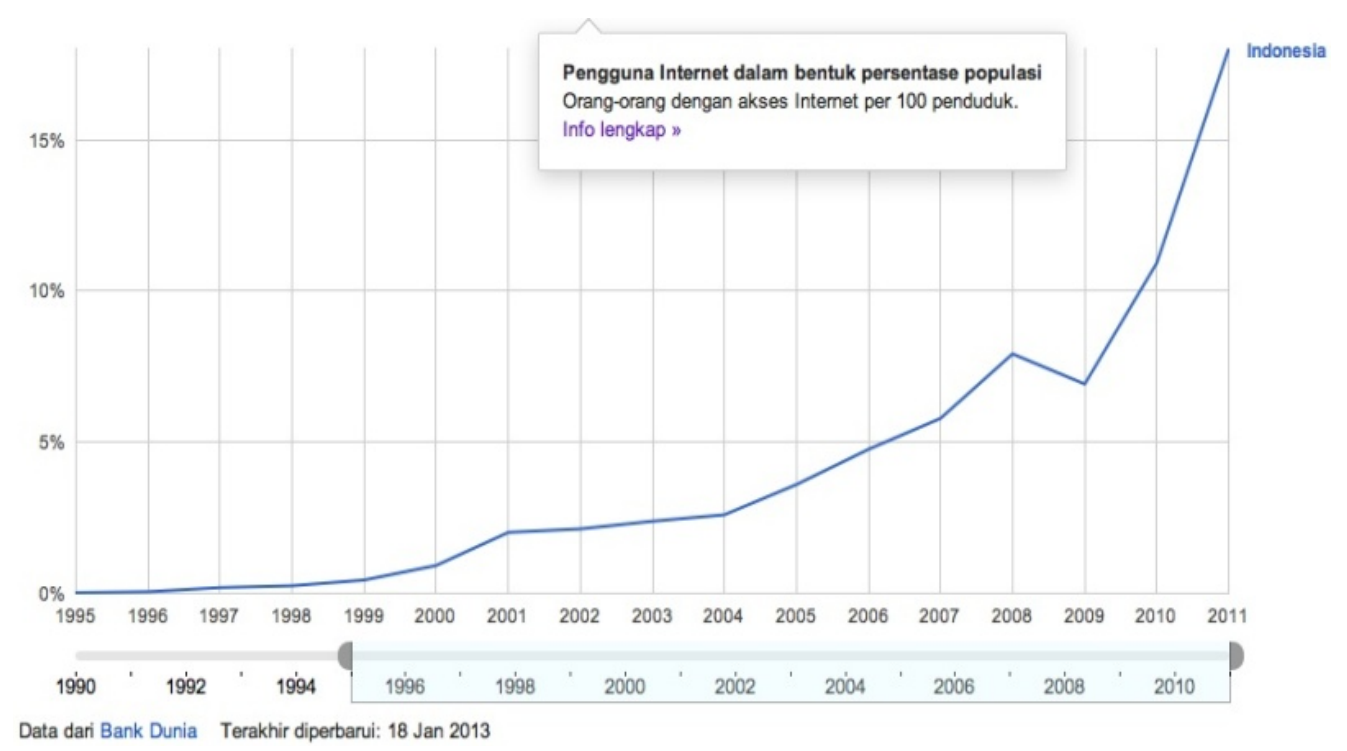

Gambar 2 Diagram Pengguna Internet di Indonesia dalam Persentase Populasi

Data tersebut merupakan data Bank Dunia terhadap pertumbuhan pengguna Internet di Indonesia hingga tahun 2011. Untuk tahun 2013 angka penggunaan internet menunjukkan lonjakan yang lebih tajam lagi. Seperti yang dilansir portal berita Kompas (Yusuf, 2012) akhir tahun lalu, Asosiasi Penyelenggara Jasa Internet Indonesia (APJII) mengungkapkan bahwa jumlah pengguna Internet di Indonesia tahun 2012 mencapai 63 juta orang atau 24,23 persen dari total populasi negara ini. Tahun depan, angka itu diprediksi naik sekitar 30 persen menjadi 82 juta pengguna dan terus tumbuh menjadi 107 juta pada 2014 dan 139 juta atau 50 persen total populasi pada 2015. APJII juga melansir perbandingan pertumbuhan internet Indonesia ini masih sejalan dengan pertumbuhan internet dunia. Indonesia menempati urutan ke delapan di seluruh dunia sementara pengguna internet global sendiri, menurut International Telecommunication Union (ITU) mencapai angka 2,421 miliar pada 2011 dari 2,044 miliar pada tahun sebelumnya. (Yusuf, 2012)

Dengan begitu Indonesia, memiliki potensi pertumbuhan jumlah pengguna Internet lebih tinggi dibandingkan negara maju seperti Korea Selatan dengan angka penetrasi Internet telah mencapai kisaran 80 persen. Hanya saja pertumbuhan di Indonesia tidak eksponensial karena luasnya wilayah negara. Pengguna Internet terbanyak saat ini masih berada di Pulau Jawa. Posisi kedua diikuti Pulau Sumatera, Sulawesi, Bali, dan Kalimantan. (Riza, 2012)

Paparan profil pengguna Internet sedianya dapat menjawab jika Indonesia sudah sepenuhnya memasuki era masyarakat informasi. Masyarakat disebut sebagai masyarakat informasi jika bercirikan: 1) adanya kebutuhan informasi yang tinggi dalam kehidupan masyarakat sehari-hari; 2) penggunaan teknologi informasi untuk kegiatan sosial, pengajaran, dan bisnis, serta kegiatan-kegiatan lainnya; dan 3) kemampuan pertukaran data digital yang cepat dalam jarak yang jauh (Straubhaar \& LaRose, 2006). Gambar 3 dan 4 berturut-turut menunjukkan akses dan penggunaan komputer dan Internet di Indonesia dan frekuensi menggunakan Internet berdasarkan kelompok pekerjaan. 


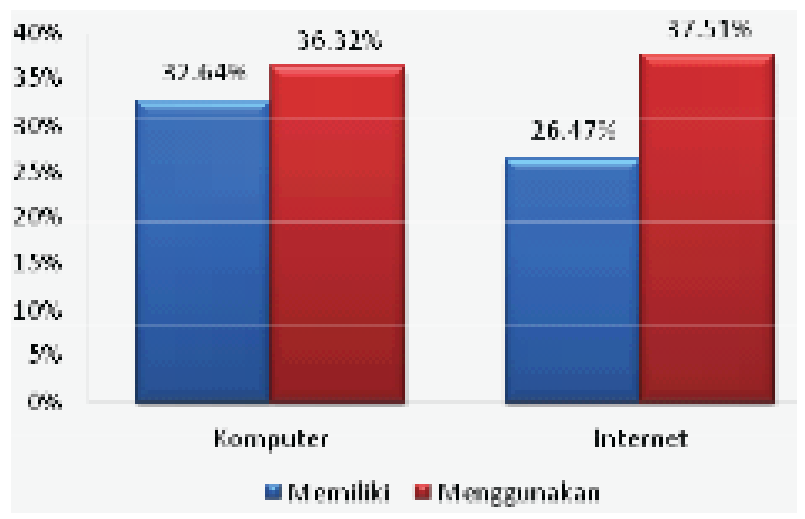

Gambar 3 Akses dan Penggunaan Komputer dan Internet (Sumber: Survei Pusdata Kominfo dalam Meiningsih, 2011)

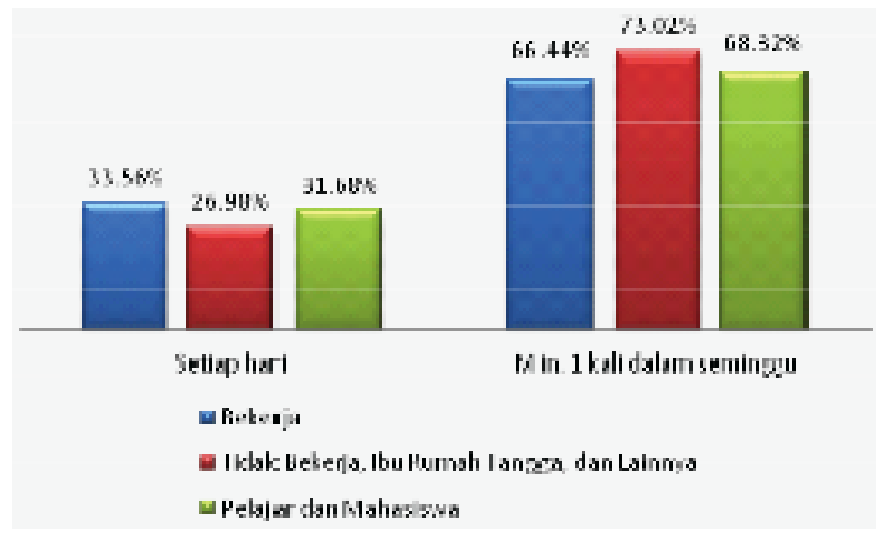

Gambar 4 Frekuensi Menggunakan Internet Berdasarkan Kelompok Pekerjaan (Sumber: Survei Pusdata Kominfo dalam Meiningsih, 2011)

Tingkat penggunaan Internet per hari oleh masyarakat Indonesia berdasarkan kelompok pekerjaan masih di bawah lima puluh persen (Meiningsih, 2011). Namun secara keseluruhan, sudah ada penetrasi dan pemanfaatan Internet oleh masyarakat dan ke depan pertumbuhannya menunjukkan peningkatan yang signifikan. Artinya, masyarakat Indonesia dapat dikatakan telah berada di masa transisi menuju masyarakat informasi.

\section{Perilaku Masyarakat Indonesia dalam Mengakses dan Mendistribusi Informasi melalui Perangkat Teknologi Informasi dan Komunikasi}

Sebagai masyarakat yang tengah berada dalam era transisi menuju masyarakat informasi, terdapat pola perubahan pada gaya hidup mereka utamanya dalam mengakses dan mendistribusi informasi. Perangkat yang digunakan tidak hanya sebatas penggunaan komputer, baik komputer pribadi atau kantor maupun sekolah, tetapi juga perangkat komunikasi nirkabel lainnya seperti telepon seluler, personal data assistant, tab atau gadget lain yang terhubung dengan Internet. Sebagai mana yang telah dibahas, perangkat komunikasi masyarakat informasi saat ini telah bertransformasi menjadi perangkat komunikasi yang tidak sekadar menawarkan fitur telekomunikasi tetapi juga akses data.

Masyarakat Informasi global saat ini menganggap perangkat komunikasi nirkabel mereka menjadi kebutuhan yang turut memengaruhi gaya hidup mereka. Seperti yang digambarkan pada Gambar 5, lebih dari 70 persen masyarakat negara pengguna perangkat komunikasi nirkabel khususnya China dan India dari benua Asia mengakui perangkat teknologi komunikasi nirkabel 
membawa mereka lebih dekat dengan relasi dan kerabat termasuk cara mereka mengetahui informasi terkait peristiwa yang tengah terjadi (Gibbs, 2012). Data ini diperoleh dari polling majalah Time terhadap 4700 responden online dan telepon yang diselenggarakan bekerja sama dengan Qualcomm.

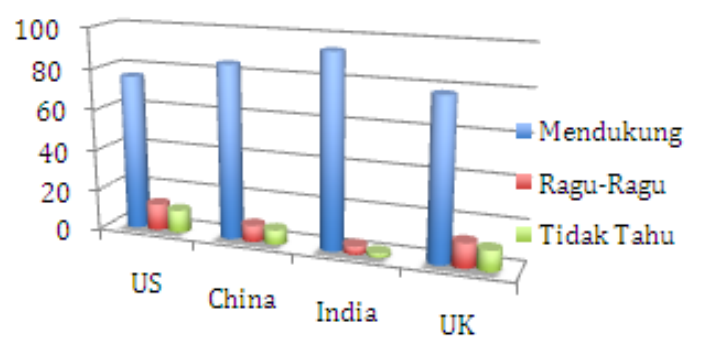

Gambar 5 Persentase Pengaruh Perangkat Teknologi Komunikasi Nirkabel (Sumber: Gibbs, 2012)

Lebih lanjut, pengaruh perangkat teknologi komunikasi terhadap gaya hidup masyarakat dunia di elaborasi sebagai berikut: 29 persen warga Amerika Serikat mengatakan hal yang pertama kali dilihat saat memulai beraktivitas setiap hari adalah perangkat gadget mereka, 62 persen warga Inggris mengatakan mereka lebih mudah terhubung dengan kerabat saat harus berpergian, 60 persen warga India mengatakan perangkat teknologi komunikasi memperbaiki kualitas hidup pada umumnya, dan 79 persen warga China mengaku mereka mudah mengakses informasi terkait perkembangan peristiwa terkini yang terjadi di sekitar mereka maupun dunia (Gibbs, 2012).

Lantas dengan situasi di Indonesia, perlu dilakukan penelitian lanjutan terhadap khalayak untuk mengetahui seberapa besar teknologi informasi dan komunikasi mengubah perilaku atau gaya hidup masyarakat Indonesia menuju era masyarakat informasi. Namun demikian, tren dan pola penggunaan Internet menunjukkan Indonesia sudah mengadopsi teknologi Internet dalam aktivitas pemenuhan kebutuhan hidup sehari-hari. Berdasarkan hasil penelitiannya, Meiningsih (2011) menggambarkan aktivitas masyarakat dalam menggunakan Internet yang dihitung berdasarkan proporsi individu dalam rumah tangga pengguna Internet dalam 12 bulan terakhir terhadap total sampel. Hasil survei menunjukkan aktivitas yang paling sering dilakukan ketika berselancar di Internet adalah membuka situs jejaring sosial, yang diakui oleh 64,43\% responden. Selain membuka situs jejaring sosial, aktivitas lain yang banyak dilakukan dengan menggunakan Internet adalah mencari informasi mengenai barang/jasa (48,55\%), mengirim dan menerima email (47,33\%), dan mengunduh film/gambar (46,98\%). Selanjutnya individu menggunakan Internet untuk aktivitas belajar dan mengakses berita melalui portal berita (Meiningsih, 2011). Agar lebih jelas, Gambar 6 menunjukkan aktivitas penggunaan Internet di Indonesia.

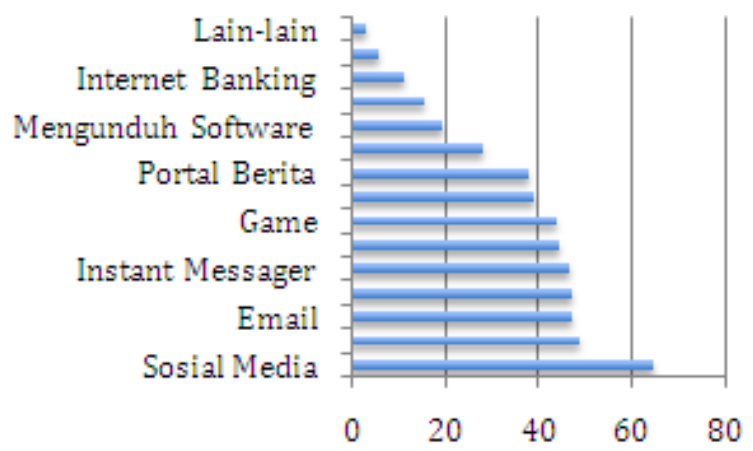

Gambar 6 Aktivitas Penggunaan Internet di Indonesia (Sumber: Meiningsih, 2011) 
Kecenderungan masyarakat Indonesia untuk menggunakan perangkat teknologi komunikasi dalam upaya memenuhi kebutuhannya makin diperjelas dengan fenomena early adopter atau suka mengadopsi teknologi mutakhir. Indonesia sebagai pasar gadget yang menjanjikan memiliki konsumen yang cenderung early adopter sehingga rela mengeluarkan biaya berlipat ganda demi memperoleh produk terbaru (Suhendro, 2012). Seakan-akan, prestise kepemilikan perangkat teknologi informasi komunikasi terkini mengalahkan level kebutuhan. Fenomena ini mudah diamati dengan mengularnya antrean masyarakat saat provider telekomunikasi dan produser perangkat teknologi komunikasi seperti Apple, Blackberry, atau Samsung tengah meluncurkan produk mutakhirnya. Karena itu, animo masyarakat Indonesia pada dasarnya terbilang positif dengan kecenderungan mereka menjadi early adopter setiap perangkat komunikasi baru yang muncul.

\section{Perkembangan Jaringan Media Sosial dan Pewarta Warga di Indonesia}

Perkembangan teknologi informasi dan komunikasi diikuti dengan perubahan gaya hidup masyarakatnya, tidak terkecuali di Indonesia. Data memperlihatkan bahwa masyarakat Indonesia yang sudah mengadopsi teknologi informasi dan komunikasi, terbilang aktif utamanya dalam menggunakan sosial media. Kemunculan Internet yang disusul dengan berbagai platform media sosial, yang melaluinya komunikasi antara manusia dapat berlangsung secara real time dengan cakupan wilayah lebih luas. Di Indonesia media sosial telah menyedot perhatian masyarakat. Saat ini hampir di seluruh kota besar warga sudah mengetahui keberadaan Facebook ataupun Twitter bahkan memiliki akun pada perangkat lunak sosial tersebut. Penggunanya dapat menjalin jaringan untuk kemudian berbagi informasi tanpa kendala jarak dan waktu. Media sosial menjadi media interaksi baru yang membuat ruang-ruang bagi masyarakat untuk saling berbagi, bercerita, dan menyalurkan ide. Akibatnya, masyarakat melakukan migrasi virtual untuk berinteraksi di ruang virtual agar dapat berinteraksi dengan pengguna lainnya. Dengan memiliki akun di sebuah media sosial seseorang dapat dikatakan telah melakukan migrasi virtual. Atau dengan kata lain, dia telah menjadi cyber citizens (warga dunia virtual) yang memungkinkan mereka berinteraksi dan menyalurkan ide di dunia virtual. Jika sudah begini, distribusi informasi di media baru sangat memiliki nilai ekonomis.

Teori Network Society Manual Castells dapat menjelaskan konsep ini. Pada era informasi, informasi merupakan modal dasar aktivitas ekonomi sebagai luaran perkembangan teknnologi informasi dan komunikasi. Aktivitas ekonomi ini kemudian berlangsung dalam jaringan sosial yang kemudian mendorong produser perangkat komunikasi untuk mengadopsi teknologi informasi dan komunikasi ke dalam produk-produknya (Flew, 2011).

Fitur perangkat komunikasi era informasi, alhasil mendukung proses meluasnya jaringan sosial virtual. Berdasarkan data AC Nielsen, di Indonesia penggunaan Internet tertinggi masih untuk jejaring sosial dengan persentase 75,3 (Suprapto \& Budiawati, 2013). Facebook dan Twitter masih mendapat tempat mayoritas masyarakat Indonesia meski perangkat android dan smartphone terus mengembangkan platform sosial media yang lebih ekslusif kepada para penggunanya seperti aplikasi perkawanan Path, portofolio karir Linked In, media sosial visual Youtube, dan masih banyak lagi. Blog sebagai aplikasi media sosial berbasis web 2.0 masih menawarkan medium komunikasi interaktif yang paling vital karena menawarkan kemampuan distribusi informasi paling kompleks. Blog juga media yang memungkinkan distribusi informasi dalam format jurnalisme, yang melaluinya informasi atau opini disajikan dengan sentuhan kreativitas (Flew, 2011).

Popularitas media sosial atau blog yang saat ini tampilannya tidak hanya mengakomodasi informasi teks tetapi juga audio visual, kemudian memberikan pengaruh besar terhadap pertumbuhan dan perkembangan citizen journalism. Lanin (2012) menjelaskan pewarta warga atau jurnalisme warga (partisipatoris) adalah pengumpulan, pelaporan, analisis, dan penyebaran berita dan informasi oleh masyarakat biasa, bukan wartawam profesional. Contoh pewarta warga di Indonesia adalah: situs (blog pribadi), situs independen seperti Kompasiana, situs kolaboratif seperti forum Wikipedia, forum seperti Kaskus, Mailing List, mikroblog seperti Twitter (Lanin, 2012). 
Dalam kurun waktu sepuluh tahun terakhir, eksistensi media sosial yang memberikan ruang kepada warga untuk berbagi informasi secara independen kian menguat. Bahkan media sosial mampu memengaruhi pembuat kebijakan negeri ini, seperti halnya media pemberitaan mainstream. Sebut saja Koin Keadilan Prita melalui media sosial Facebook dan blog http://koinkeadilan.com yang berhasil menggugah masyarakat Indonesia untuk mengumpulkan koin. Koin yang terkumpul mencapai lebih besar dari nilai denda tuntutan pencemaran nama baik oleh RS. Omni Internasional, yakni sebesar 204 juta rupiah (Respati, 2009).

Kasus yang menyita perhatian penggiat media sosial lainnya adalah kasus Cicak versus Buaya. Memanfaatkan situs perkawanan Facebook, gerakan 1 Juta Facebookers memaksa penanganan kasus Bibit dan Chandra yang dianggap mengerdilkan peran KPK harus disikapi dengan bijak oleh penguasa negeri ini (Arif, 2009). Belakangan gerakan ini berhasil mengumpulkan dukungan lebih dari satu juta pengguna Facebook dengan memberikan "like" dan mengikuti postingan berita terkini terkait kasus Cicak dan Buaya.

Yang paling memperlihatkan peran aktif warga adalah munculnya blog sebagai media komunikasi yang mereka kelola sendiri, bukan media mainstream. Seperti misalnya http://merapi.combine.or.id sebagai media komunikasi dan informasi tentang gunung Merapi. Awalnya media itu sebatas media berbagi informasi antarberbagai radio komunitas yang tergabung dalam Jalin Merapi. Namun belakangan, informasi dapat diakses publik termasuk warga Indonesia yang berada di luar negeri (Hermanto, 2008). Jurnalisme warga ini sekaligus menjadi geliat baru warga agar tak sekedar menjadi objek informasi tapi juga berpartisipasi menjadi sumber informasi di tengah dominasi media massa mainstream. Kasus penyampaian informasi awan panas meluncur hingga radius $60 \mathrm{~km}$ saat letusan gunung Merapi 2010 silam oleh salah satu media massa mainstream dapat menjadi pelajaran betapa media pewarta warga dapat menjadi alternatif media untuk mendapatkan informasi akurat, utamanya saat terjadinya simpang siur informasi di tengah bencana (Anam, 2011).

\section{Transformasi Media Pemberitaan menuju Era informasi}

Fenomena tumbuh pesatnya media sosial berikut pewarta warga tidak dapat diabaikan begitu saja oleh praktisi industri media pemberitaan ekstrim. Pasalnya pola produksi dan distribusi informasi telah mengalami pergeseran seiring dengan penerapan perangkat komunikakasi berbasis teknologi informasi dan komunikasi. Media pemberitaan ekstrim sebenarnya telah melakukan sinergi dengan melakuan transformasi pada distribusi pemberitaannya. Transformasi sendiri adalah perubahan yang dilakukan berdasarkan suatu saran atau masukan yang berujung berupa output perubahan (Goldhaber, 1993). Ada upaya mengubah atau membuat berbeda dari segi produksi hingga penyajian informasi yang dilakukan media mainstream saat ini.

Stasiun televisi berita Metro TV, misalnya, tidak cukup dengan hanya menyairkan informasi di media televisi terestrial, tetapi juga menyiarkan konten berita di ranah media online metrotvnews.com. Metro TV juga memberikan kesempatan kepada pewarta warga untuk mengirimkan karya jurnalistiknya untuk ditayangkan di salah satu program acaranya yaitu Wideshot. Program yang mengapresiasikan karya jurnalisme warga ini disiarkan setiap hari senin-jumat jam 13.00 hingga 17.00 WIB. Selain itu Metro TV juga memberikan pelatihan melalui kegiatan roadshow ke berbagai daerah, termasuk memberikan anugerah bagi karya jurnalistik warga untuk kategori peristiwa maupun feature (Aryono, 2012).

Stasiun televisi mainstream lainnya adalah SCTV dengan program berita Liputan 6. Selain menayangkan karya jurnalistik warga di program berita reguler Liputan 6 akhir pekan, portal berita liputan6.com juga memberikan ruang atau kanal khusus bernama Citizen6. Setiap warga masyarakat dari beragam latar belakang dapat mengirimkan konten yang menarik, actual, dan bisa dipertanggungjawabkan. Konten untuk Citizen6 bisa berupa peristiwa yang terjadi di sekitar, lifestyle, 
kesehatan, wisata, kuliner, olahraga, tentang kegiatan komunitas, dan lainnya. Tim Citizen6 juga memberi kebebasan kepada semua onliner untuk menyampaikan gagasan-gagasannya selama tidak menyalahi atau bertentangan dengan SARA atau suku agama dan ras (Tim Citizen6, 2013).

Transformasi media pemberitaan dengan mensinergikan teknologi informasi dan komunikasi cepat latau lambat harus dilakukan praktisi industri media pemberitaan mainstream di Indonesia termasuk media televisi. Seperti halnya konsep televisi era digital yang dijabarkan Dominick (2009), transformasi tak cukup hanya dengan mengadopsi teknologi penyiaran digital tetapi juga outlet berita masa kini, yang penyiaran juga berbasis broadband atau teknologi Internet. Pengguna dalam hal ini khalayak adalah unsur penting yang mengendalikan arus konten yang disiarkan atau user-generated content, terkait dengan perubahan pola masyarakat era informasi dalam mengakses dan mendistribusikan berita (Dominick, 2009).

Lebih jauh para praktisi industri media pemberitaan mainstream memaparkan bagaimana transformasi yang dilakukan, dalam hal ini praktisi di redaksi pemberitaan Liputan 6. Sejak 1 April 2009, Liputan 6 SCTV memberlakukan sistem manajemen News Center (Litbang Liputan 6, 2009). Pemimpin redaksi kala itu menerangkan perubahan yang terjadi tidak cuma sebatas infrastruktur dan pembenahan struktur organisasi yang diiringi dengan deskripsi kerja kru liputan 6. Perubahan juga terjadi pada pengembangan konten berita antar-outlet, di bawah satu payung, sehingga konten tidak sebatas untuk kebutuhan tayangan teresterial namun juga platform media baru portal berita liputan6.com yang mengalami proses inovasi. Proses inovasi ini sendiri termasuk di dalamnya memberikan ruang bagi khalayak dalam hal ini pemirsa liputan 6 untuk berpartisipasi, tidak hanya dalam tataran memberikan feedback (umpan balik) terhadap suatu tayangan berita, tetapi juga aktif menjadi sumber berita.

Liputan 6 dalam hal ini tim Citizen6 yang mengembangkan kanal pewarta warga menyadari, di era 2.0 ketika semua orang telah terhubung, publik dapat menjadi menjadi objek sekaligus subjek sebuah berita. Selama ini mereka memperoleh informasi dari media mainstream baik cetak, elektronik maupun digital. Namun pada akhirnya tidak semua jurnalis profesional mampu melaporkan semua peristiwa yang ada. Faktor pemicunya adalah kendala tempat atau waktu sehingga tidak bisa melaporkan dengan cepat. Pada saat itulah pewarta warga bisa mengambil peran sebagai jurnalis untuk melaporkan kejadian penting yang ada di sekitarnya.

Platform media sosial lain yang juga tidak boleh diabaikan adalah mikroblog Twitter dan Fans Page di media sosial perkawanan Facebook. Tim khusus dibentuk untuk kemudian diberdayakan untuk mengelola akun media sosial tersebut (Twitter: @liputan6.com). Melalui akun ini Liputan 6 dapat menjembatani 386 ribu follower menuju sumber informasi lengkap di portal berita liputan6.com. Di saat yang sama follower dapat menyebarkan informasi Liputan 6 lebih luas lagi, ke jaringan komunitas virtual yang dikembangkan para follower.

\section{SIMPULAN}

Masyarakat Indonesia saat ini berada dalam fase transisi menuju masyarakat era informasi. Dalam proses ini terdapat pergeseran pola cara masyrakat mengakses dan mendistribusikan informasi. Hal ini merupakan konsekuesi perubahan gaya hidup mereka saat mengaplikasikan perangkat komunikasi berbasis teknologi informasi. Berkembangnya jaringan sosial virtual menjadi babak selanjutnya dalam era transisi menuju masyarakat informasi. Masyarakat Indonesia kemudian menjalin jaringan untuk berbagi informasi tanpa kendala jarak dan waktu. Dalam arti kata lain masyarakat melakukan migrasi virtual untuk berinteraksi di ruang virtual agar dapat berinteraksi dengan pengguna lainnya. Inovasi fitur perangkat komunikasi saat ini menawarkan medium 
komunikasi yang kian interaktif. Satu yang paling vital di antaranya Blog, aplikasi sosial media berbasis web 2.0. yang menawarkan kapasitas produksi dan distribusi informasi paling kompleks dan membuka keran kreativitas warga. Situasi ini mendorong berkembangnya citizen journalism (partisipatoris) yang khalayak dapat berperan aktif dalam kegiatan pengumpulan, pelaporan, analisis, dan penyebaran berita dan informasi seperti halnya jurnalis profesional.

Fenomena makin berkembangnya media sosial dan pergeseran pola masyarakat dalam mengonsumsi informasi ini tidak dapat diabaikan begitu saja oleh praktisi industri media pemberitaan mainstream. Media pemberitaan mainstream sebenarnya telah melakukan sinergi dengan melakuan transformasi pada distribusi pemberitaannya. Satu hal yang tidak kalah penting, industri media mainstream juga perlu mengetahui penggunaan berbagai platform media sosial masyarakat era informasi. Mengabaikan peran aktif masyarakat informasi hanya akan membuat industri media pemberitaan ditinggalkan khalayak. Lebih lanjut, pada era masyarakat informasi, nantinya semua orang akan terhubung, publik dapat menjadi menjadi object sekaligus subject sebuah berita. Publik tidak hanya memperoleh informasi dari media mainstream baik cetak, elektronik, maupun digital. Karena pada akhirnya, tidak semua jurnalis profesional mampu melaporkan semua peristiwa termasuk mengikuti tren konsumsi berita masyarakat informasi.

\section{DAFTAR PUSTAKA}

Anam, K. (2011, 28 September). Jurnalisme Warga saat Erupsi Merapi. Diakses 10 Maret 2013 dari http://www.combine.or.id/refleksi-jurnalisme-warga-dalam-bencana-merapi-2010/

Aoyama, Y., and Castells, M. (2002). An Empirical assessment of the Informational Society. International Labour Review, 141. Geneva: ILO.

Arif, A. (2009, 31 Oktober). Sejuta Dukungan buat Bibit S Rianto dan Chandra M Hamzah. Diakses dari http://nasional.kompas.com/read/2009/10/31/05040985/Sejuta.Dukungan.buat.Bibit.S.Rianto. dan.Chandra.M.Hamzah

Aryono, A. M. (2012, 23 November). CJC 2012: Pewarta Warga asal Solo Raih CJC Metro TV. Diakses 10 Maret 2013 dari http://www.solopos.com/2012/11/23/cjc-2012-2-pewarta-wargaasal-solo-raih-cjc-metro-tv-350266

Brown, M. C. (2012, August 27). A Camera Goes Anywhere. Time: The Wireless Issue, 189(9).

Dominick, J. R. (2009). The Dynamic of Mass Communication, Media in the Digital Age. New York: McGraw-Hill.

Flew, T. (2008). New Media: an Introduction, 3rd Ed. Victoria: Oxford.

Gibbs, N. (2012). Your Life is Fully Mobile. TIME: The Wireless Issue, 189(9), Aug. 27.

Goldhaber, G. M. (1993). Organization Communication: Behaviour Organization. New York: McGraw-Hill.

Hermanto, B. (2007, Oktober). Televisi Komunitas: Media Pemberdayaan Masyarakat. Jurnal Komunikasi, 2(1). Yogyakarta: UII 
(2008). Berbagi Informasi Menuai Simpati. Kombinasi: Pusat Sumber Daya Media Komunitas. Diakses 10 Maret 2013 dari http://web.kombinasi.net/wpcontent/uploads/Berbagi-Informasi-Menuai-Simpati.Budhi_1.pdf

International Telecommunication Union. (2010). Measuring the Information Society. Diakses dari https://www.itu.int/ITU-D/ict/publications/idi/material/2010/MIS_2010_without_annex_4e.pdf

Internet World Stats. (2012). Asia Top Countries June 30, 2012. Diakses dari http://internetworldstats.com/stats3.htm

Kriyantono, R. (2012). Teknik Praktis Riset Komunikasi. Jakarta: Kencana.

Lanin, I. (2012). Jurnalisme warga yang efektif dan dapat dipertanggungjawabkan. Seminar Bahasa Kompas, 20 Oktober 2012. Diakses 10 Maret 2013 dari http://www.slideshare.net/ivanlanin/jurnalisme-warga-yang-efektif-dan-dapatdipertanggungjawabkan

Meiningsih, S. (2011). Kajian Indikator TIK Indonesia: Pola Akses dan Penggunaan TIK oleh Rumah Tangga dan Individu. Jurnal Penelitian Pos dan Informatika, 1(1), 5-20, Sep. 2011. Jakarta: Kemkominfo.

Pacey, A. (2000). The Culture of Technology. Massachussets: The MIT Press.

Respati, W. (2009, 14 Desember). Koin untuk Prita Diberikan Lewat Konser. Diakses 10 Maret 2013 dari http://news.liputan6.com/read/254502/koin-untuk-prita-diberikan-lewat-konser

Suhendro, P. A. (2012). 2013: Teknologi Ceruk Baru iPhone. Bloomberg Businessweek, No.50 edisi 27 Desember 2012 - 09 Januari 2013

Straubhaar, J., and LaRose, R. (2006). Media Now, Understanding Media, Culture and Technology. Belmont: Thomson Wadsworth.

Yusuf, O. (2012, 13 Desember). 2013, Pengguna Internet Indonesia Bisa Tembus 82 Juta. Diakses 10 maret $2013 \quad$ dari http://tekno.kompas.com/read/2012/12/13/10103065/2013.pengguna.internet.indonesia.bisa.te mbus.82.juta

Riza, B. (2012, 12 Desember). Jumlah Pengguna Internet Indonesia Terus Melonjak. Diakses 10 Maret 2013 dari http:/www.tempo.co/read/news/2012/12/12/072447763/Jumlah-PenggunaInternet-Indonesia-Terus-Melonjak

Tim Citizen6. (2013, 5 Maret). Yuk Jadi Pewarta Warga di Citizen 6. Diakses 10 Maret 2013 dari http://news.liputan6.com/read/527816/yuk-jadi-pewarta-warga-di-citizen6

Suprapto, H., dan Budiawati, A. D. (2013, 6 Maret). Nielsen: Jaringan Sosial Turun, Pengguna Internet Naik. Diakses 10 Maret 2013 dari http://bisnis.news.viva.co.id/news/read/395508nielsen--jejaring-sosial-turun--pengguna-internet-naik 